University of Nebraska - Lincoln

DigitalCommons@University of Nebraska - Lincoln

2015

Translocation of Humpback Chub into Tributary Streams of the Colorado River: Implications for Conservation of Large- River Fishes

Jonathan Spurgeon

Craig P. Paukert

Brian D. Healy

Melissa Trammell

Dave Speas

See next page for additional authors

Follow this and additional works at: https://digitalcommons.unl.edu/natlpark

This Article is brought to you for free and open access by the National Park Service at DigitalCommons@University of Nebraska - Lincoln. It has been accepted for inclusion in U.S. National Park Service Publications and Papers by an authorized administrator of DigitalCommons@University of Nebraska - Lincoln. 
Authors

Jonathan Spurgeon, Craig P. Paukert, Brian D. Healy, Melissa Trammell, Dave Speas, and Emily OmanaSmith 


\title{
Translocation of Humpback Chub into Tributary Streams of the Colorado River: Implications for Conservation of Large- River Fishes
}

\author{
Jonathan J. Spurgeon*1 \\ Missouri Cooperative Fish and Wildlife Research Unit, Department of Fisheries and Wildlife Sciences, \\ University of Missouri, 302 Anheuser-Busch Natural Resources Building, Columbia, Missouri 65211, USA
}

\section{Craig P. Paukert}

U.S. Geological Survey, Missouri Cooperative Fish and Wildlife Research Unit, Department of Fisheries and Wildlife Sciences, University of Missouri, 302 Anheuser-Busch Natural Resources

Building, Columbia, Missouri 65211, USA

\section{Brian D. Healy}

U.S. National Park Service, Grand Canyon National Park, 1824 South Thompson Street, Suite 200, Flagstaff, Arizona 86001, USA

\section{Melissa Trammell}

U.S. National Park Service, Intermountain Region, 324 South State Street, Suite 200, Salt Lake City, Utah 84111, USA

\section{Dave Speas}

U.S. Bureau of Reclamation, 125 South State Street, Salt Lake City, Utah 84138, USA

\section{Emily Omana-Smith}

U.S. National Park Service, Grand Canyon National Park, 1824 South Thompson Street, Suite 200,

Flagstaff, Arizona 86001, USA

\begin{abstract}
The Humpback Chub Gila cypha, a large-bodied, endangered cyprinid endemic to the Colorado River basin, is in decline throughout most of its range due largely to anthropogenic factors. Translocation of Humpback Chub into tributaries of the Colorado River is one conservation activity that may contribute to the expansion of the species' current range and eventually provide population redundancy. We evaluated growth, survival, and dispersal following translocation of approximately 900 Humpback Chub over a period of 3 years $(2009,2010$, and 2011) into Shinumo Creek, a tributary stream of the Colorado River within Grand Canyon National Park. Growth and condition of Humpback Chub in Shinumo Creek were consistent among year-classes and equaled or surpassed growth estimates from both the main-stem Colorado River and the Little Colorado River, where the largest (and most stable) Humpback Chub aggregation remains. Based on passive integrated tag recoveries, 53\% $(=483 / 902)$ of translocated Humpback Chub dispersed from Shinumo Creek into the main-stem Colorado River as of January 2013, 35\% leaving within $25 \mathrm{~d}$ following translocation. Annual apparent survival estimates within Shinumo Creek ranged from 0.22 to 0.41 , but were strongly influenced by emigration. Results indicate that Shinumo Creek provides favorable conditions for growth and survival of translocated Humpback Chub and could support a new population if reproduction and recruitment occur in the future. Adaptation of translocation strategies of Humpback Chub into tributary streams ultimately may refine the role translocation plays in recovery of the species.
\end{abstract}

*Corresponding author: jonathan.spurgeon@ huskers.unl.edu

${ }^{1}$ Present address: School of Natural Resources, University of Nebraska-Lincoln, 243A Hardin Hall, Lincoln, Nebraska 68583, USA.

Received September 2, 2014; accepted January 6, 2015 
Translocation of imperiled lotic fishes to areas outside their presently occupied range can create population redundancy and may ameliorate persistent threats by anthropogenic changes, including disruption of natural flow regimes and nonnative species introductions (Lawler and Olden 2011). Alteration of natural flow regimes through construction of impoundments and land use trends has altered the magnitude, duration, rate of change, water temperature, and sediment supply of seasonal flows (Poff et al. 1997). Subsequent disruption of spawning cues (Nesler et al. 1988; Goodman et al. 2013), increased mortality of larval and juvenile fishes (Freeman et al. 2001; Humphries et al. 2002), and reduced habitat complexity and connectivity (Galat et al. 1998; Pracheil et al. 2013) has occurred. In addition, the introduction and establishment of nonnative fishes often accompanies altered flow regimes and can reduce the presence, abundance, and distribution of native fish populations through competition for space and food, as well as predation (Cucherousset and Olden 2011). Therefore, establishing new populations of native fishes by translocating animals into new areas that have minimal anthropogenic modification and few nonnative species may be a viable conservation and management strategy, especially as flow regime alteration and climate change continues (Olden et al. 2011; Schwartz et al. 2012).

In the Colorado River basin of the southwestern USA, intensive river regulation and introduced species are largely responsible for the decline and local extirpation of the basin's riverine fishes (Yard et al. 2011; Gido et al. 2013). The endangered Humpback Chub Gila cypha is a large, long-lived cyprinid endemic to the Colorado River basin, and is found in the main-stem Colorado River and a few of its major tributaries (Valdez and Ryel 1995). Large-scale river regulation, predation, and competition from nonnative fishes have all contributed to Humpback Chub declines (Yard et al. 2011; Minckley et al. 2003). The current distribution of Humpback Chub includes six extant populations, the largest of which inhabits the lower Colorado River basin in the Colorado River below Glen Canyon Dam (GCD) within Grand Canyon National Park, Arizona. This lower-basin population consists of nine aggregations along the Colorado River (Valdez and Ryel 1995; Paukert et al. 2006) between river kilometers (rkm) 74 and 368. However, these main-stem aggregations typically consist of fewer than 200 adult fish each (Valdez and Ryel 1995; Trammell et al. 2002), except for the Little Colorado River (hereafter, Little Colorado) aggregation, which has fluctuated between 5,000-11,000 adults over the past 2 decades (Coggins and Walters 2009).

Humpback Chub growth, survival, and recruitment in the main-stem Colorado River is limited by cold hypolimnetic releases from GCD and by predation from nonnative predators, such as Brown Trout Salmo trutta and Rainbow Trout Onchorhynchus mykiss (Keading and Zimmerman 1983; Robinson et al. 1998; Yard et al. 2011). Humpback Chub successfully spawn and recruit in the Little Colorado, which is the largest tributary of the Colorado River in Grand Canyon, and is mostly unregulated (Keading and Zimmerman 1983; Finch et al. 2015). However, survival of age-0 and juvenile Humpback Chub in the Little Colorado is variable and somewhat uncertain (Valdez and Ryel 1995; Yackulic et al. 2014). Additionally, young Humpback Chub that do emigrate from the Little Colorado take twice as long to reach adulthood due to cooler water temperatures and are approximately $40 \%$ less likely to transition into adulthood (Yackulic et al. 2014). Therefore, assisted dispersal may provide an advantage to Humpback Chub due to the potential for the translocated cohort to avoid density-dependent factors in the Little Colorado (Pine et al. 2013) and the prevalence of nonnative predators in the Little Colorado reach of the main-stem Colorado River (Yard et al. 2011). Additional tributary environments along the Colorado River that afford relatively unaltered flow and temperature regimes may provide additional opportunities to conserve Humpback Chub.

Management agencies have adopted a series of goals and actions to minimize the extinction risks to Humpback Chub. Translocation into tributaries outside of the Little Colorado has been cited as one tool to reduce the effects of river alteration and increase the current distribution of Humpback Chub (Valdez et al. 2000; Trammell et al. 2012). The 1995 Biological Opinion (USFWS 1995) on the operation of GCD included the establishment of a second spawning aggregation of Humpback Chub downstream of GCD as a reasonable and prudent alternative; the 2011 Biological Opinion (USFWS 2011) calls for coordinated efforts to "expand the role of tributaries and their ability to contribute to the growth and expansion of mainstem aggregations" as a conservation measure to the operation of GCD. More specifically, conservation measures in the 2008 and 2011 Biological Opinions (USFWS 2008, 2011) directed the U.S. Bureau of Reclamation to coordinate with and assist the U.S. National Park Service (NPS) and other state and federal agencies in the translocation of Humpback Chub to Shinumo, Havasu, and Bright Angel creeks (Figure 1), three tributaries within Grand Canyon National Park. A feasibility study commissioned by the GCD Adaptive Management Program and U.S. Geological Survey, Grand Canyon Monitoring and Research Center previously evaluated several different alternatives to establish a second population of Humpback Chub in Grand Canyon, including translocation into tributary streams (Valdez et al. 2000). Three tributaries (Bright Angel, Shinumo, and Havasu) were determined to be suitable in meeting life history needs of Humpback Chub based on measures of habitat availability, food base, temperature, and flow regime (Valdez et al. 2000). Shinumo Creek was selected for an initial translocation attempt because of its segregation from the Colorado River by a waterfall, lower density of predatory nonnative fish, and the watershed is completely protected within Grand Canyon National Park. Historical fish community data for Shinumo Creek and most of the other tributaries of the Colorado River in Grand Canyon are limited for years preceding 

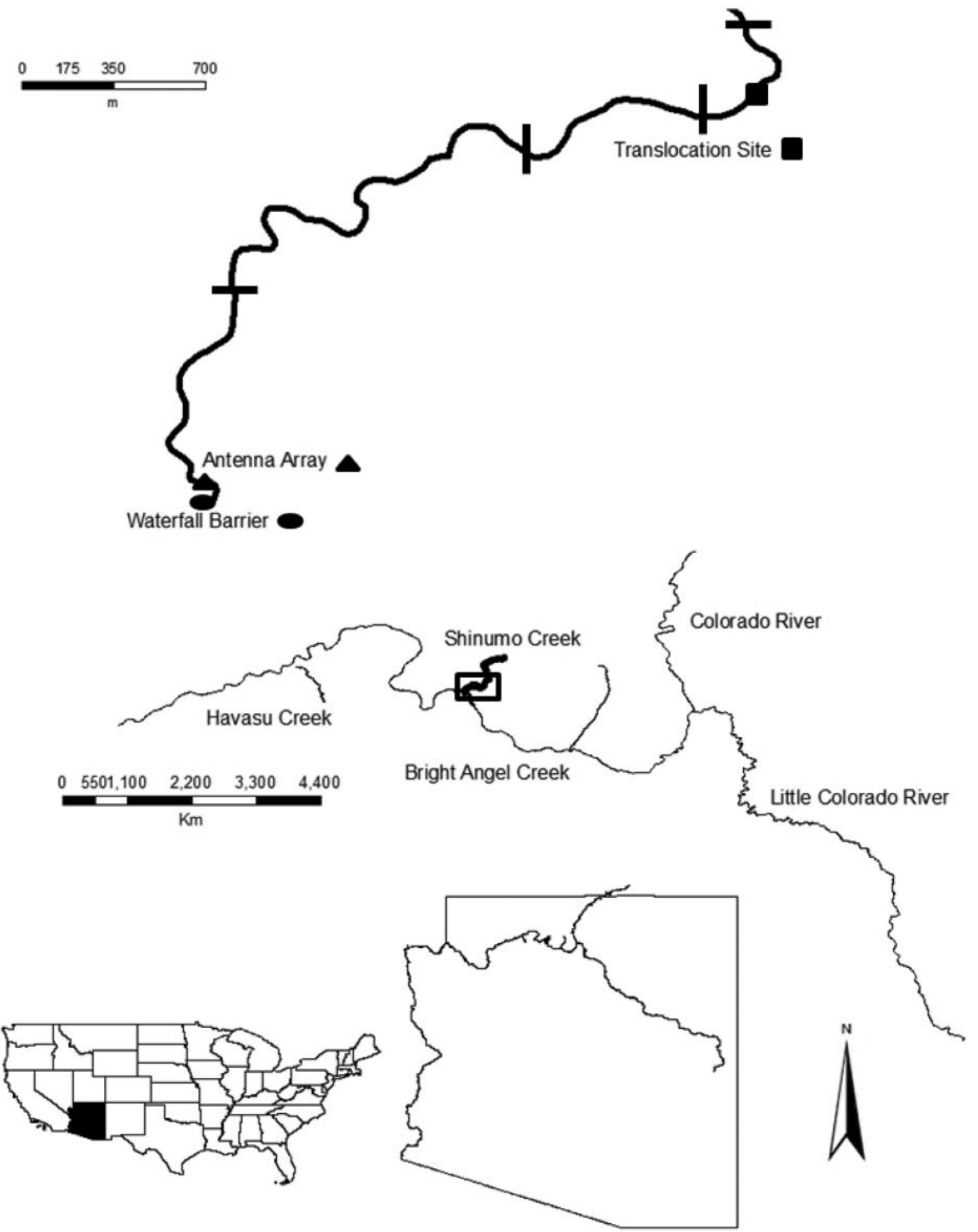

FIGURE 1. Location of Shinumo Creek in relation to Little Colorado River and Havasu and Bright Angel creeks of Arizona. Sample reaches are designated in sequential order from the mouth (i.e., reach 1-4) by solid black bars. The locations of the waterfall barrier separating Shinumo Creek from the main-stem Colorado River (solid oval), the dual antenna array (solid triangle), and the translocation site (solid square) are also shown. 
extensive river regulation, the invasion and introduction of warmwater nonnative species to the Colorado River basin in the late 1800 s, and stocking of nonnative coldwater trout species within Grand Canyon streams in the 1920s. However, sampling did occur within Shinumo Creek in the early 1990s (Allan 1993) and in cooperation with the NPS in 2004, 2005, and 2009 (NPS, unpublished data), but no Humpback Chub were recorded. Seasonal flooding of the Colorado River and pooling in the mouth of Shinumo Creek would probably have resulted in river stage exceeding the height of the waterfall before impoundment of the Colorado River, effectively connecting the river to the creek, allowing for passage of fish upstream. However, this connection no longer occurs effectively isolating Shinumo Creek from the main-stem fish community.

Experimental translocation of young Humpback Chub into tributaries with water temperature and flow regimes more typical of historical conditions in the Colorado River may result in a suite of outcomes (Trammell et al. 2012): (1) an additional aggregation that exhibits successful spawning and recruitment, (2) an aggregation that exhibits sufficient survival and growth, whereby Humpback Chub grow and supplement main-stem aggregations through emigration from tributaries to the main stem, or (3) Humpback Chub may not survive, grow, or augment main-stem aggregations. Outcome (1) could provide population redundancy in the wake of catastrophic loss of the Little Colorado population, and outcome (2) would provide both population redundancy and individuals to supplement other existing aggregations. Outcomes (1) and (2) may be attained through establishment of a translocated population, which will depend on adequate survival and growth of released individuals resulting in reproduction and recruitment to the population (Pine et al. 2013). However, prior to growth, survival, and reproduction, establishment may ultimately depend on postrelease emigration. Translocation efforts have been attempted for Humpback Chub within the Little Colorado, where between 2003 and 2008 approximately 1,450 individuals were released above Chute Falls, a natural barrier 14 rkm upstream from the population in the lower Little Colorado. The premise was that relatively warmer water temperatures compared with the main stem and a greater distance from main-stem predators (i.e., trout) would increase growth and survival of juveniles (Van Haverbeke et al. 2013). Humpback Chub above Chute Falls grew rapidly and resulted in range expansion of the species, but many of these individuals subsequently migrated downstream, where they appear to have assimilated back with the primary Little Colorado population (Van Haverbeke et al. 2013).

Although much information was gathered regarding translocation of Humpback Chub from initial efforts at Chute Falls in the Little Colorado, no studies have evaluated how Humpback Chub may respond to translocation into tributary streams outside the Little Colorado. In addition, the majority of translocation studies have centered on terrestrial organisms, and few if any studies have evaluated the translocation of largeriver fishes (but see Mueller and Wydoski 2004). Therefore, a need exists to monitor post-translocation trends in key population variables to refine strategies for future translocations of large-river fishes, including Humpback Chub.

In this study, our objectives were to assess growth and body condition, survival, and dispersal of Humpback Chub following the first 3 years of a translocation project within Grand Canyon National Park and determine how those rate functions compare with other established main-stem Humpback Chub aggregations, including the Little Colorado. In addition, we provide evidence of movement of translocated Humpback Chub to adjacent main-stem aggregations, potential reproduction within translocation sites, and evidence of recruitment to mature size.

\section{METHODS}

Study Site.-Shinumo Creek is a 20-km tributary to the Colorado River in Grand Canyon National Park (northern Arizona; Figure 1) that originates from Modred and Abyss River Springs at an elevation approximately $1,406 \mathrm{~m}$ and drains an area of approximately $220 \mathrm{~km}^{2}$, which is entirely within the boundaries of Grand Canyon National Park. The creek maintains a perennial average flow rate of $0.26 \mathrm{~m}^{3} / \mathrm{s}$ and flooding occurs during spring snowmelt and late summer (i.e., JulySeptember) monsoons; seasonal water temperatures range approximately $3^{\circ} \mathrm{C}$ to $25^{\circ} \mathrm{C}$ (NPS, unpublished data). The mean width of the stream is $4 \mathrm{~m}$, and the riparian zone consists of a densely vegetated understory (horsetail Equisetum spp.) and overhanging trees (willow Salix spp. and cottonwood Populus spp.). A 4-m waterfall near the mouth isolates Shinumo Creek from further colonization by main-stem Colorado River native and nonnative fishes. The fish community in Shinumo Creek during this study, prior to translocation of Humpback Chub, consisted of native Bluehead Sucker Catostomus discobolus, Speckled Dace Rhinichthys osculus, and established nonnative Rainbow Trout. Prior to translocation, no Humpback Chub population existed within Shinumo Creek.

Translocation process.-From 2008 through 2010, 902 age0 and age-1 Humpback Chub were translocated from the Little Colorado to Shinumo Creek. Fish were collected for translocation from the Little Colorado in mid to late summer or fall each year using baited hoop nets or seines. Individuals were reared for up to 1 year at either Southwest Native Aquatic Resources and Recovery Center (formerly Dexter National Fish Hatchery), New Mexico, in 2008 and 2009 or at Bubbling Ponds State Native Fish Facility, Arizona, in 2010. At these facilities they underwent flow-training and parasite treatment to prevent cross-tributary contamination, received a passive integrated transponder (PIT) tag, and were weighed (g) and measured (mm; TL). Humpback Chub were released into Shinumo Creek (302 in June 2009 and 300 in both 2010 and 2011; Figure 2) immediately following fish community 

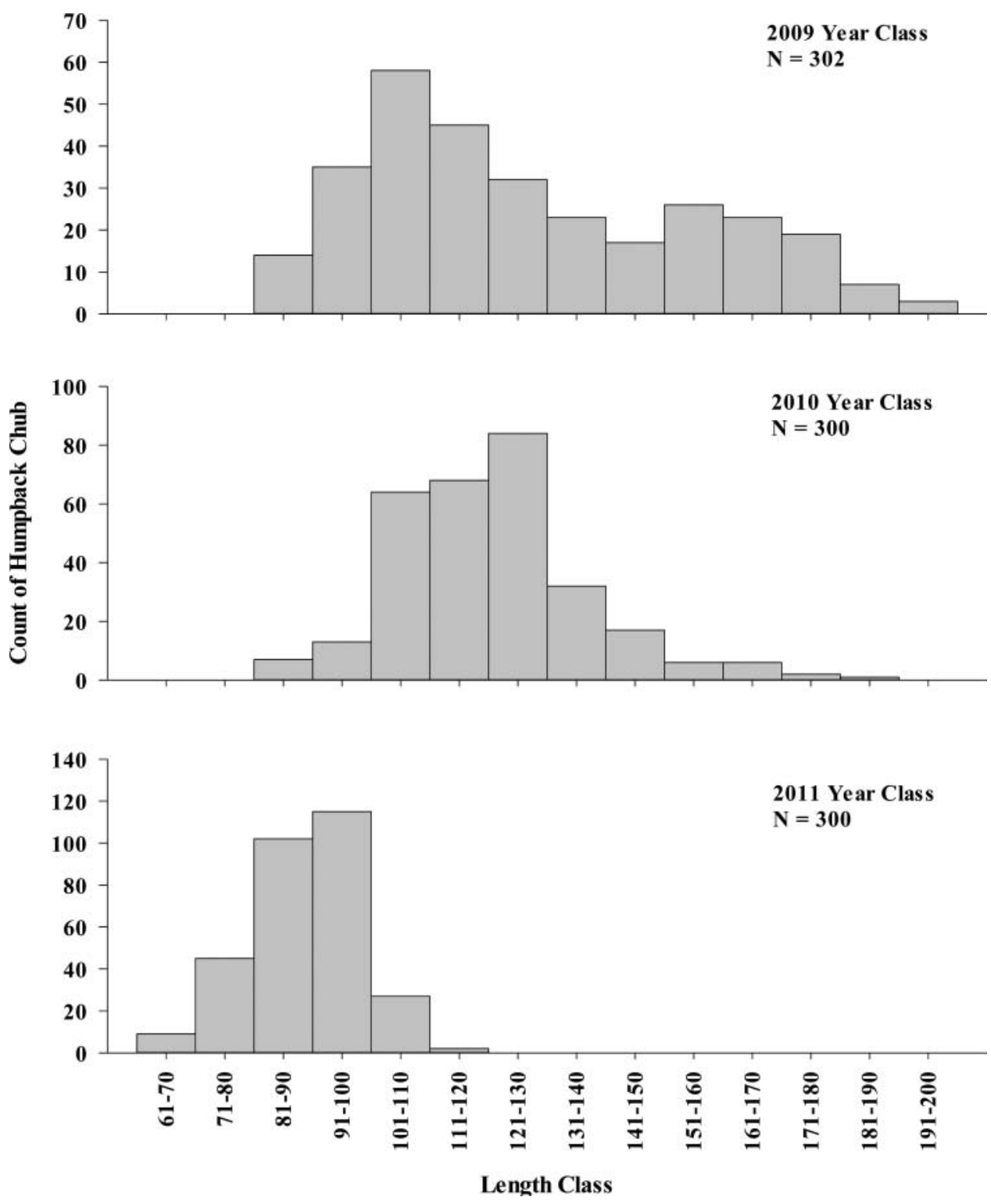

FIGURE 2. Size structure (mm; TL) of Humpback Chub released into Shinumo Creek, Arizona, for each of the three translocation years in June 2009, 2010, and 2011.

sampling. During each translocation, Humpback Chub were transported from hatcheries to Grand Canyon National Park's South Rim, divided into two aerated 113-L coolers and flown by helicopter to Shinumo Creek, where they were tempered for approximately $60 \mathrm{~min}$ until temperatures in release buckets were within $1{ }^{\circ} \mathrm{C}$ of creek temperature. Removal of nonnative Rainbow Trout (through back-pack electrofishing and angling) was done concurrent with translocation efforts to increase chances of survival and growth of translocated Humpback Chub (George et al. 2009), and approximately 3,900 Rainbow Trout were subsequently removed from Shinumo Creek prior to and during translocation through 2012. Removal efforts were performed before each new translocation of Humpback
Chub, and electrofishing was performed in areas largely upstream of the translocation areas, thereby imposing minimal influence on Humpback Chub.

Sample design.-The lower $2.8 \mathrm{rkm}$ of Shinumo Creek was divided into four sample reaches from the mouth to the translocation release area (reach $1=800 \mathrm{~m}$, reach $2=1,175 \mathrm{~m}$, reach $3=600 \mathrm{~m}$, and reach $4=250 \mathrm{~m}$ ), based upon visual estimation of suitable hoop-net sampling locations within each reach. These sampling reaches were in sequential order from the mouth of Shinumo Creek and were contiguous (Figure 1). All Humpback Chub were released into reach 4, where hydrological barriers consisting of plunge pools approximately $1 \mathrm{~m}$ in height were expected to minimize movement of Humpback 
Chub upstream of the release area. These reaches were sampled 6 d each June and September of 2009, 2010, 2011, and 2012 to determine growth, body condition, and survival. June samples occurred before the new cohorts were translocated to minimize human influence in the stream. Mini hoop nets (50 $\times 100 \mathrm{~cm}, 6-\mathrm{mm}$ nylon mesh, single $10-\mathrm{cm}$ throat), and minnow traps $(3.18-\mathrm{mm}$ mesh, $25 \times 25 \times 43 \mathrm{~cm})$ baited with Purina AquaMax trout food were placed in deep pool ( 0.5 to $>1 \mathrm{~m}$ ) and run habitats within each reach. Hoop nets were set each day in two of the four reaches; two minnow traps were also set per hoop net to expand coverage of shallow water and more heterogeneous habitats not accessible with larger hoop nets. Two teams of three to four people set a total of six hoop nets in reaches 1,3 , and 4 , while nine hoop-nets were used in reach 2 to provide coverage of that longer reach. All reaches were sampled two times per sampling occasion to increase capture probability. All recaptured Humpback Chub were measured $(\mathrm{mm}$; TL), weighed $(\mathrm{g})$, and PIT tag numbers were recorded. In addition, we positioned two full duplexing PIT tag antennas near the mouth of Shinumo Creek downstream from the translocation site and $100 \mathrm{~m}$ upstream of the waterfall, which prevented movement back into the stream (Zydlewski et al. 2006; Figure 1). These antennas were located about $4 \mathrm{~m}$ apart and covered the entire width of the stream.

Data analysis.-We determined seasonal and annual absolute growth from recaptures of individual Humpback Chub. Seasons were defined as summer (June-September) and winter (September-June). To determine daily growth rates $(\mathrm{mm} / \mathrm{d})$, we divided the absolute growth by the number of days between capture events beginning from the day Humpback Chub were tagged and measured at the hatchery; Humpback Chub were not measured the day of release into Shinumo Creek. Following tagging, Humpback Chub cohorts were held for $28 \mathrm{~d}$ (2009), $13 \mathrm{~d}$ (2010), and $47 \mathrm{~d}$ (2011) to allow tagging wounds to heal and ensure minimal posttagging mortality and tag loss occurred prior to release. We compared growth rates over the first summer among the three year-classes using ANOVA (Program R; AOV) followed by posthoc comparisons using Tukey's honestly significant difference (HSD) in Program R (R Development Core Team 2014). To compare condition of translocated Humpback Chub to other aggregations throughout their range, we determined relative weight $\left(W_{r}\right)$ for Humpback Chub using the length-specific standard weight equation developed by Didenko et al. (2004) for fish $>120 \mathrm{~mm}$ TL, the minimum size recommended by Didenko et al. (2004).

We used Program MARK to fit Cormack-Jolly-Seber (CJS; Lebreton et al. 1992) models to live recapture data collected in June and September 2009, 2010, 2011, and 2012 (Cooch and White 2011). The basic input into the CJS model is the encounter history of each individual, which is used to parameterize apparent annual survival $(\phi)$ and recapture probability $(\rho)$. The apparent survival estimates obtained with CJS models do not represent true survival, but are interpreted as the probability of true survival and site fidelity (Williams et al. 2002). Therefore, one critical component of this estimate is emigration. The model cannot determine the fate of unknown fish, which could have died, remained in Shinumo Creek and survived, or have emigrated from the system. Therefore, apparent survival is interpreted as a combination of these three factors. We developed a full combination of time dependent-i.e., season, $\phi(t) \rho(t)$, and independent, $\phi(.) \rho($.$) - models to determine if monthly apparent survival$ estimates and capture probability differed among sampling occasions using length at translocation as a covariate in the models (for both $\phi$ and $\rho$ ). Time dependent models assessed differences in survival and capture probabilities from June to September and September to June. We adjusted the model structure in Program MARK by incorporating the appropriate time intervals between sampling periods to provide a monthly apparent survival estimate (e.g., June to September $2010=3$ months). An annual survival estimate for time-independent models was calculated as the product of the monthly survival estimates (i.e., annual survival $=\phi_{(\text {Month) }}{ }^{12}$ ). We derived variance estimates and confidence intervals for the survival probabilities using the Delta method (Powell 2007). Similarly, an annual survival estimate for time-dependent models was calculated as the product of the interval specific survival estimates, e.g., annual survival $=\phi_{(\text {Jun }- \text { Sep })} \times \phi_{(\text {(Oct-May) }}$. We used Akaike information criterion corrected for small sample sizes $\left(\mathrm{AIC}_{c}\right)$ to select the most parsimonious model among the candidate set. Apparent survival estimates were determined for each cohort. Because there were three different years (cohorts) of translocations, the temporal length of the analysis of each cohort differed. For example, the 2009 cohort was analyzed separately from June 2009 to September 2012, whereas the 2011 cohort was analyzed only from June 2011 to September 2012. Additional model structures were considered including band recovery models and live-resight models (using antenna data and recaptures in the main-stem Colorado River). At the time of analysis, limited numbers of recaptures prevented precise estimation of demographic parameters using live-resight methods, and our data structure did not conform to band recovery models because individuals were seen again after detection at the antenna array and completely left the study area (Williams et al. 2002).

We determined emigration of Humpback Chub using the dual antenna array. They were considered emigrated from Shinumo Creek if they were detected at antenna 1 (i.e., furthest upstream antenna) then antenna 2 (i.e., downstream antenna) and never detected again, or were only detected at antenna 2. Humpback Chub dispersal was summarized by hour, day, month, and year from June 2009 until January 2013. In addition, we determined if increased water stage (based upon a gauge station installed in Shinumo Creek near the remote antenna), particularly during spring runoff from snowmelt and summer monsoons, or changes in water temperature resulted in increased out-migration rates. We used generalized linear 
TABLE 1. Growth estimates for Humpback Chub between sampling periods in Shinumo Creek, Arizona. Summary statistics could not be calculated (NC) for 2009 year-class in certain time intervals when few to no Humpback Chub were caught. Asterisk following 2011 cohort indicates fish were measured on May 5, 2011 prior to release on June 11, 2011.

\begin{tabular}{|c|c|c|c|c|c|}
\hline \multirow[b]{2}{*}{ Cohort and period } & \multirow[b]{2}{*}{$N$} & \multicolumn{2}{|c|}{ Absolute growth (mm) } & \multicolumn{2}{|c|}{ Daily growth $(\mathrm{mm} / \mathrm{d})$} \\
\hline & & Mean (SE) & Range & Mean (SE) & Range \\
\hline \multicolumn{6}{|c|}{2009} \\
\hline Jun 2009-Jul 2009 & 93 & $6(0.5)$ & $1-39$ & $0.1(0.01)$ & $0.00-0.66$ \\
\hline Jul 2009-Sep 2009 & 37 & $22(1.18)$ & $3-44$ & $0.36(0.02)$ & $0.05-0.73$ \\
\hline Jun 2009-Sep 2009 & 98 & $25(0.84)$ & $7-65$ & $0.21(0.01)$ & $0.06-0.55$ \\
\hline Jun 2009-Jun 2010 & 21 & $36(2.14)$ & $19-52$ & $0.09(0.01)$ & $0.4-0.13$ \\
\hline Sep 2009-Jun 2010 & 11 & $11(2.37)$ & $1-27$ & $0.04(0.01)$ & $0.00-0.10$ \\
\hline Jun 2010-Sep 2010 & 7 & $33(4.52)$ & $12-44$ & $0.39(0.05)$ & $0.14-0.52$ \\
\hline Sep 2010-Jun 2011 & 1 & $10(\mathrm{NC})$ & $\mathrm{NC}$ & $0.03(\mathrm{NC})$ & NC \\
\hline Jun 2011-Sep 2011 & 3 & $28(4.18)$ & $20-33$ & $0.33(0.05)$ & $0.24-0.39$ \\
\hline Sep 2011-Jun 2012 & 1 & $22(\mathrm{NC})$ & $\mathrm{NC}$ & $0.08(\mathrm{NC})$ & $\mathrm{NC}$ \\
\hline Jun 2012-Sep 2012 & 0 & $\mathrm{NC}$ & $\mathrm{NC}$ & $\mathrm{NC}$ & $\mathrm{NC}$ \\
\hline \multicolumn{6}{|c|}{2010} \\
\hline Jun 2010-Sep 2010 & 57 & $25(0.76)$ & $10-35$ & $0.26(0.01)$ & $0.11-0.38$ \\
\hline Jun 2010-Jun 2011 & 30 & $37(1.48)$ & $21-54$ & $0.10(0.00)$ & $0.10-0.15$ \\
\hline Sep 2010-Jun 2011 & 8 & $12(1.92)$ & $1-20$ & $0.04(0.01)$ & $0.00-0.70$ \\
\hline Sep 2010-Sep 2011 & 13 & $48(2.04)$ & $38-65$ & $0.13(0.01)$ & $0.10-0.18$ \\
\hline Jun 2011-Sep 2011 & 16 & $36(1.55)$ & $24-50$ & $0.42(0.02)$ & $0.28-0.59$ \\
\hline Sep 2011-Jun 2012 & 16 & $18(1.6)$ & $4-29$ & $0.07(0.006)$ & $0.01-0.10$ \\
\hline Jun 2012-Sep 2012 & 15 & $23(1.8)$ & $14-38$ & $0.27(0.02)$ & $0.18-0.44$ \\
\hline \multicolumn{6}{|c|}{2011} \\
\hline Jun 2011-Sep 2011 & 134 & $48(0.81)$ & 30-94 & $0.38(0.01)^{*}$ & $0.23-0.74 *$ \\
\hline Sep 2011-Jun 2012 & 62 & $25(0.73)$ & $11-36$ & $0.09(0.002)$ & $0.04-0.13$ \\
\hline Jun 2011-Jun 2012 & 90 & $65(0.96)$ & $43-95$ & $0.18(0.003)^{*}$ & $0.12-0.26^{*}$ \\
\hline Jun 2012-Sep 2012 & 52 & $27(1.16)$ & $13-44$ & $0.32(0.013)$ & $0.15-0.51$ \\
\hline
\end{tabular}

models (family $=$ binomial) in Program $\mathrm{R}$ where emigration was recorded as a binary response and the stream temperature and stage readings for that time were taken (stream stage and temperature measurements were taken automatically at the dual antenna array and later downloaded). Emigration and stream stage and temperature data were analyzed from June 2009 to September 2011.

\section{RESULTS}

\section{Growth and Condition}

Humpback Chub mean annual growth was $36 \mathrm{~mm}$ TL (SD $=9.8$, range $=19-52 \mathrm{~mm} \mathrm{TL}, n=21$, June 2009 to June 2010) for the 2009 year-class, was $37 \mathrm{~mm} \mathrm{TL}(\mathrm{SD}=8.1$, range $=21-54 \mathrm{~mm} \mathrm{TL}, n=30$, June 2010 to June 2011) for the 2010 year-class, and was $65 \mathrm{~mm}$ TL $(\mathrm{SD}=9.2$, range $=$ 43-95 mm TL, $n=90$, June 2011 to June 2012) for the 2011 year-class. Absolute summer growth over the first summer (i.e., June to September of translocation year) were similar for the 2009 and 2010 year-classes (ANOVA: $F=274.5, \mathrm{df}=2$, Tukey's HSD, $P=0.896$ ) and averaged $25 \mathrm{~mm}$ TL or
$0.28 \mathrm{~mm} / \mathrm{d}$ (range $=0.08-0.71 \mathrm{~mm} / \mathrm{d}, n=98$ ) for the 2009 year-class; $24 \mathrm{~mm}$ TL or $0.31 \mathrm{~mm} / \mathrm{d}$ (range $=0.13-0.44 \mathrm{~mm} /$ $\mathrm{d}, n=57)$ for the 2010 year-class. The 2011 year-class, which also had the smallest mean length at translocation (Figure 2), averaged higher growth than both the 2009 and 2010 yearclasses $($ mean $=48 \mathrm{~mm}$ or $0.38 \mathrm{~mm} / \mathrm{d}$, range $=0.23$ $0.74 \mathrm{~mm} / \mathrm{d}, n=134)$ during the first summer in Shinumo Creek (ANOVA: $F=274$, df $=2$, Tukey's HSD, $P<0.001$ ). As expected with reduced water temperatures over winter, winter growth was lower than summer for both the 2009 and 2010 year classes (Table 1).

At translocation, Humpback Chub mean relative weight was $91(\mathrm{SE}=0.59 ; n=157$; range $=54-122)$ for the 2009 year-class and $99(\mathrm{SE}=0.64$, range $=80-144, n=157)$ for the 2010 year-class. Relative weight at translocation for the 2011 year-class could not be calculated because no individuals exceeded the $120-\mathrm{mm}$ TL minimum length to calculate $W_{r}$ (Didenko et al. 2004). However, mean $W_{r}$ values for the 2011 year-class in September 2011 following translocation in June 2011 averaged $96(\mathrm{SE}=1.12$, range $=69-134, n=112)$. Mean $W_{r}$ at recapture was above 90 for all sampling periods and year-classes except September 2010 (right after a fire in 
TABLE 2. Model-based likelihoods from Program MARK describing apparent annual survival of Humpback Chub in Shinumo Creek, Arizona, using a Cormack-Jolly-Seber (CJS) mark-recapture design. Akaike information criteria corrected for small sample sizes (AIC ) $_{\text {were }}$ used to select the most parsimonious model among the candidate set. Phi is the probability of survival, $\rho$ is the recapture probability, $t$ indicates a time variant model parameter, PIM is the Parameter Index Matrix, and total length (TL) was used as a covariate in the model structure (for both phi and $\rho$ ); Dev. $=$ the model deviance.

\begin{tabular}{|c|c|c|c|c|c|c|}
\hline Model & $\mathrm{AIC}_{c}$ & $\Delta \mathrm{AIC}_{c}$ & $\mathrm{AIC}_{c}$ weights & Likelihood & $\begin{array}{l}\text { Number of } \\
\text { parameters }\end{array}$ & Dev. \\
\hline \multicolumn{7}{|c|}{2009} \\
\hline$\{\operatorname{Phi}(t) \rho(.) \operatorname{PIM}\} \mathrm{TL}\}$ & $1,168.03$ & 2.39 & 0.21 & 0.30 & 7 & $1,153.83$ \\
\hline$\{$ Phi(.) $\rho($.$) PIM \}$ TL $\}$ & $1,170.55$ & 4.91 & 0.06 & 0.09 & 3 & $1,164.51$ \\
\hline$\{\operatorname{Phi}(t) \rho(.) \operatorname{PIM}\}$ & $1,178.90$ & 13.26 & 0.00 & 0.00 & 7 & $1,164.70$ \\
\hline$\{\operatorname{Phi}(.) \rho($.$) PIM \}$ & $1,179.59$ & 13.95 & 0.00 & 0.00 & 2 & $1,175.57$ \\
\hline$\{\operatorname{Phi}(t) \rho(t) \operatorname{PIM}\}$ & $1,180.34$ & 14.70 & 0.00 & 0.00 & 11 & $1,157.86$ \\
\hline \multicolumn{7}{|c|}{2010} \\
\hline$\{\operatorname{Phi}(t) \rho(.) \operatorname{PIM}\}$ & 660.26 & 0.00 & 0.28 & 1.00 & 3 & 654.20 \\
\hline$\{\operatorname{Phi}(t) \rho(t) \operatorname{PIM}\} \mathrm{TL}\}$ & 663.26 & 2.99 & 0.06 & 0.22 & 6 & 651.04 \\
\hline$\{$ Phi(.) $\rho($.$) PIM \}$ & 671.86 & 11.60 & 0.00 & 0.00 & 2 & 667.83 \\
\hline$\{$ Phi(.) $\rho($.$) PIM \}$ TL $\}$ & 673.45 & 13.19 & 0.00 & 0.00 & 3 & 667.39 \\
\hline \multicolumn{7}{|c|}{2011} \\
\hline$\{\operatorname{Phi}(t) \rho(.) \operatorname{PIM}(\mathrm{TL}\}$ & 986.09 & 0.00 & 0.44 & 1.00 & 5 & 975.98 \\
\hline$\{\operatorname{Phi}(t) \rho(.) \operatorname{PIM}\}$ & 986.93 & 0.83 & 0.29 & 0.66 & 4 & 978.85 \\
\hline$\{\operatorname{Phi}(t) \rho(t) \operatorname{PIM}\}$ & 988.06 & 1.97 & 0.17 & 0.37 & 5 & 977.94 \\
\hline$\{\operatorname{Phi}(t) \rho(t) \mathrm{TL}\}$ & 989.24 & 3.15 & 0.09 & 0.21 & 7 & 975.02 \\
\hline$\{$ Phi(.) $\rho(t)$ PIM $\}$ TL $\}$ & 995.62 & 9.53 & 0.00 & 0.01 & 5 & 985.51 \\
\hline$\{$ Phi(.) $\rho(t)$ PIM $\}$ & 997.09 & 11.00 & 0.00 & 0.00 & 4 & 989.01 \\
\hline
\end{tabular}

the watershed in September 2010 deposited ash and sediment in the stream), when the 2010 year-class averaged 81 ( $\mathrm{SE}=$ 1.41).

\section{Survival}

The best-fit model describing translocated Humpback Chub apparent annual survival for the 2009 year-class was the $\phi(.) \rho(t)$ model with total length as a covariate, indicating monthly survival was dependent on length and was constant through the course of our study but capture probabilities differed among sampling occasions (Table 2). For both the 2010 and 2011 year-classes the $\phi(t) \rho($.$) model was the best-fit; how-$ ever, for the 2010 year-class the $\phi(.) \rho(t)$ model had nearly equal weight. Also, total length was again associated with the top model explaining Humpback Chub survival in 2011, although the same model without total length also was well supported (likelihood value $=0.66$ ). Monthly apparent survival estimates were $0.88(95 \% \mathrm{CI}=0.85-0.90)$ for the 2009 year-class (time constant model), $0.79(95 \% \mathrm{CI}=0.72$ $0.85)$ and $0.91(95 \% \mathrm{CI}=0.88-0.94)$ for the 2010 year-class (time variable model), and $0.86(95 \% \mathrm{CI}=0.83-0.89)$ and $0.95(95 \% \mathrm{CI}=0.93-0.96)$ for the 2011 year-class (time variable model). Annual apparent survival estimates (i.e., which includes emigration) were $0.22(95 \% \mathrm{CI}=0.16-0.28)$ for the 2009 year-class and $0.23(95 \% \mathrm{CI}=0.12-0.37)$ for the 2010 year-class, and $0.41(95 \% \mathrm{CI}=0.36-0.46)$ for the 2011 yearclass. Therefore, about $22 \%$ to $41 \%$ of Humpback Chub (depending on year-class) remained and survived in Shinumo Creek.

\section{Emigration}

From June 2009 to January 2013, 47-59\% of the Humpback Chub emigrated from Shinumo Creek (depending on year-class), 45-48\% leaving within the first year following 


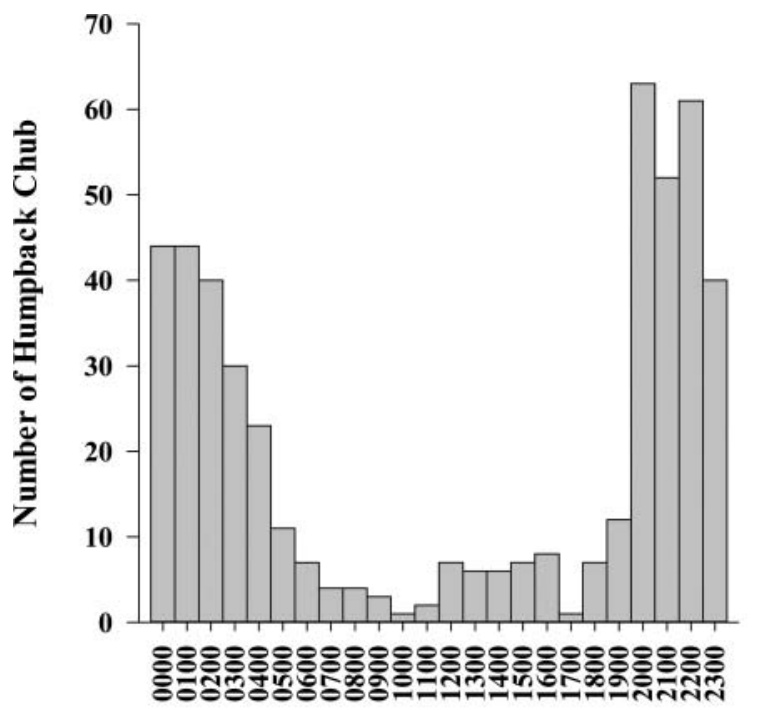

Time of Day

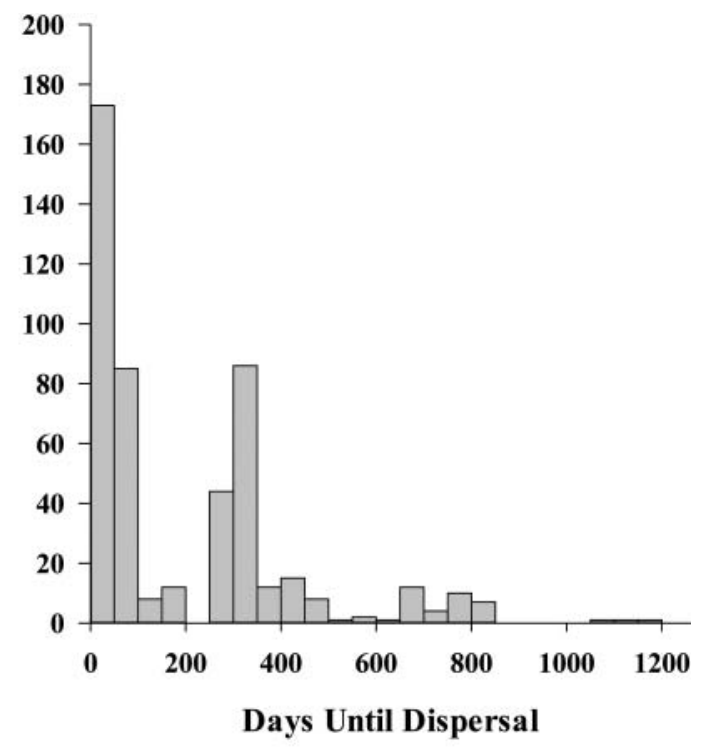

FIGURE 3. Time of day (hours) when emigration occurred (left panel) and the elapsed time (d; right panel) before emigration for translocated Humpback Chub in Shinumo Creek, Arizona.

translocation. Emigration immediately following translocation was high and occurred predominately at night; nearly $35 \%$ left within the first $25 \mathrm{~d}$ after translocation (Figure 3). Additionally, 27\% of Humpback Chub that left, emigrated approximately 300-350 d post translocation, which corresponds to the month of April and increasing temperatures and flows (Figure 3). An estimated 59\% of the 2009 yearclass had emigrated, $48 \%$ leaving within the first year. Similarly, 54\% of the 2010 year-class and $47 \%$ of the 2011 year-class emigrated during the study period; $45 \%$ of the 2010 year-class and $47 \%$ of the 2011 year-class left within the first year following translocation. During approximately the first $90 \mathrm{~d}$ after translocation (i.e., June 23 -August 1, 2011), 22\% of the 2011 year-class emigrated, which is equal to the 2010 year-class but higher than the $14 \%$ of the 2009 year-class. During the first night in Shinumo Creek, $100 \%$ of the emigrants in 2009 were from the 2009 year-class (i.e., the only year-class present), $88 \%$ of the emigrants in 2010 were from the 2010 year-class, and 100\% of the emigrants in 2011 were from the 2011 yearclass. Emigration was positively associated with stream stage (GLM: $Z=5.622, P<0.0001$ ) and water temperature (GLM: $Z=4.865, P<0.0001$; Figure 4).

\section{DISCUSSION}

Translocated Humpback Chub grew rapidly in Shinumo Creek and demonstrated similar or better growth rates than both the established Little Colorado population (0.02$0.28 \mathrm{~mm} / \mathrm{d}$; Finch et al. 2015) and main-stem Colorado River $(0.07-0.16 \mathrm{~mm} / \mathrm{d}$; Finch et al. 2015). Young Humpback Chub that emigrated from the Little Colorado into the Colorado River experienced less growth than individuals that remained in the tributary (Yackulic et al. 2014). Therefore, Shinumo Creek may provide growth benefits similar to the Little Colorado and better than the main-stem Colorado River for chub
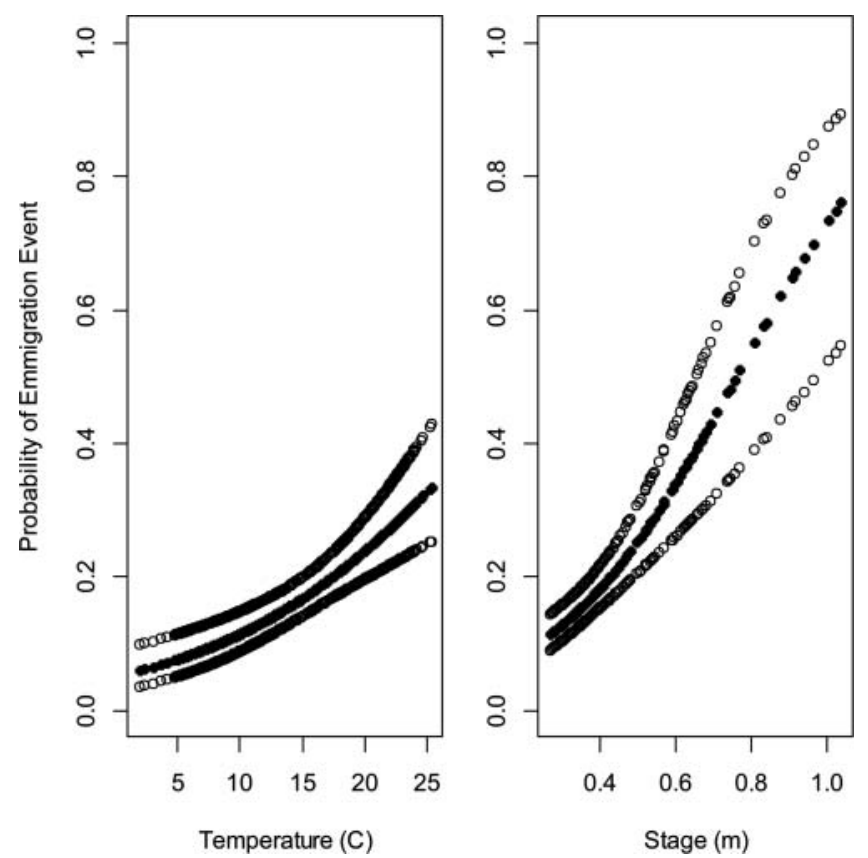

FIGURE 4. Predicted probability of an emigration event occurring for Humpback Chub in Shinumo Creek, Arizona. Predictions were based on generalized linear models, solid circles depicting the estimated probability and open circles the $95 \%$ confidence intervals. 
that remain and grow before emigrating to the main-stem Colorado River. The high growth associated with the 2011 yearclass may also be partly due to growth in hatchery because these fish were held the longer ( $47 \mathrm{~d}$ ) than the other two yearclasses. However, both previous year-classes were held for relatively short periods $(2009=28 \mathrm{~d}, 2010=13 \mathrm{~d})$ and still averaged higher growth rates than the Little Colorado and mainstem aggregations. In addition, relative weights were typically at 90 or above. Higher relative weights may suggest suitable tissue energy content (e.g., Brown and Murphy 1991) and prey availability (e.g., Hubert et al. 1994; Porath and Peters 1997) and, thus, may suggest Humpback Chub have sufficient energy reserves or may not be food limited in Shinumo Creek (Spurgeon et al., in press). A recent population model examining alternative translocation strategies for Humpback Chub in Colorado River tributaries showed growth rates comparable to the Little Colorado may increase the chance of establishment in tributary streams (Pine et al. 2013), presumably through increased survival. Therefore, because translocated chub in Shinumo Creek grew at similar rates to established, naturally recruiting populations, Shinumo Creek probably provides appropriate rearing conditions for young Humpback Chub.

Apparent annual survival estimates of Humpback Chub ranged from 0.22 to 0.41 , which are comparable to survival estimates from both the main-stem Colorado River and the Little Colorado (Yackulic et al. 2014). These estimates include emigration and thus indicate that $22-41 \%$ of the Humpback Chub remained and survived in Shinumo Creek. Because we have an estimate of emigration, true survival estimates of Humpback Chub that remained in Shinumo Creek can be estimated and compared with previous survival estimates from the main-stem Colorado River and the Little Colorado. The 2011 cohort had an annual survival rate of 0.41 . Therefore, after 1 year we expect approximately 123 Humpback Chub to remain in Shinumo Creek and 177 individuals were lost to either death or dispersal from the system. Additionally, we know 141 (47\%) of the 2011 cohort emigrated from Shinumo Creek $(0.47 \times 300=141$ emigrants $)$. The estimated number of the 2011 cohort that died during their first year in Shinumo Creek is subsequently 36 (i.e., $177-141$ ), and the estimated 1 -year true survival is 0.88 , i.e., $1-(36 \mathrm{dead} / 300$ translocated). The same process applied to the 2009 cohort, which was in the system for 3 years, results in an in-stream true survival estimate of 0.84 (e.g., annual survival $=0.22$, dispersal $=0.59$, fish lost $=299$, known emigrants $=178$, estimated died $=121$, estimated 3-year survival $=0.60$, and estimated annual in-stream survival $=0.60^{1 / 3}=0.84$ ). For the 2010 cohorts, which were in the system for 2 years, the process results in an in-stream true survival estimate of 0.77 (e.g., annual survival $=0.23$, dispersal $=0.54$, fish lost $=284$, known emigrants $=162$, estimated died $=122$, estimated 2year survival $=0.60$, and estimated annual in-stream survival $=0.60^{1 / 2}=0.77$ ). Therefore, survival of subadult Humpback Chub in Shinumo Creek was greater than in both the main- stem Colorado River (37-67\%; Finch 2012) and Little Colorado (75.5\%; Valdez and Ryel 1995). Causes of mortality in Shinumo Creek following translocation are open to speculation. Predation by nonnative fishes has been implicated in reducing the survival in previous riverine fish translocation efforts (Marsh and Brooks 1989; Marsh et al. 2005). Despite the presence of bite marks noted on live Humpback Chub (NPS, unpublished data), direct mortality due to predation by Rainbow Trout (which were concurrently removed from Shinumo Creek during this study; Spurgeon et al., in press) was not observed. Nevertheless, piscivory rates of Rainbow Trout on native fishes in Colorado River tributaries were about 45\% (Whiting et al. 2014; Spurgeon et al., in press). However, the limited number of Humpback Chub relative to other prey sources and our limited time at Shinumo Creek (i.e., $14 \mathrm{~d} /$ year) may have precluded the capture of a Rainbow Trout that recently consumed a Humpback Chub. Other sources of mortality, including delayed stress (although not observed), following tempering and release may have also occurred. The only evidence of predation were from the five PIT tags from translocated Humpback Chub found in a midden beneath a Great Blue Heron Ardea herodias roost adjacent to Shinumo Creek (Brian Healy personal observation).

Main-stem Colorado River monitoring efforts have resulted in the capture of translocated Humpback Chub that have emigrated from Shinumo Creek, indicating dispersed individuals survive and may contribute to main-stem Humpback Chub aggregations. For instance, the majority of Humpback Chub captures in the main stem were translocated fish (39 fish or $73 \%$ of all captures in 2013; NPS, U.S. Geological Survey, and U.S. Fish and Wildlife Service, unpublished data). Additionally, two translocated individuals were detected by a PIT tag antenna array in the Little Colorado, more than $72 \mathrm{rkm}$ from the release point in Shinumo Creek (W. Persons, U.S. Geological Survey, Grand Canyon Monitoring and Research Center, personal communication). Therefore, translocated Humpback Chub that subsequently emigrated from Shinumo Creek mixed with existing main-stem aggregations and survived. As additional recaptures within Shinumo Creek occur and resightings in the main-stem Colorado River increase, additional model structures (e.g., mark-recapture live-resight models; multistate models) may provide insight on survival of all translocated individuals (not just in Shinumo Creek) and dispersal probabilities.

Dispersal immediately following release has been implicated in preventing establishment in previous fish translocation studies (Minckley 1995). Similar to our study, Van Haverbeke et al. (2013) found high levels of emigration by Humpback Chub within the Little Colorado. Humpback Chub emigration immediately following release (i.e., hours to days) may reduce the short-term probability of initial establishment (Pine et al. 2013) by increasing susceptibility of the remaining population to further losses due to extreme environmental conditions (Deredec and Courchamp 2007). Juvenile Humpback 
Chub exhibit movement out of the Little Colorado during flooding conditions (Yackulic et al. 2014). Increased movement out of Shinumo Creek may be in response to high-flow periods with subsequent changes in water temperature, or possibly due to reproductive behavior. Establishing a population of Humpback Chub was equally likely from two contrasting scenarios (e.g., few large versus many small individuals; Pine et al. 2013); however, initial emigration from the system, as observed in our study, increased the probability of extirpation from the translocation stream, particularly when future emigration events are likely. Therefore, controlling the high levels of initial emigration may be critical in the initial establishment of Humpback Chub following translocation.

Our study has demonstrated Humpback Chub in Shinumo Creek grow and maintain body condition, so Shinumo Creek may serve to provide rearing opportunities that enable translocated chub to colonize nearby aggregations within the mainstem Colorado River. Growth coupled with delayed emigration could support meta-population connectivity by augmenting the main-stem Humpback Chub population (Minckley 1995). Tweed et al. (2003) suggested dispersal is highly dependent on the matrix of established populations, whereby dispersing individuals may settle with larger populations and restore meta-population connectivity. Juvenile and adult Humpback Chub, while often displaying considerable site fidelity in the main-stem Colorado River (Valdez and Ryel 1995; Paukert et al. 2006), do transition between tributary and main-stem systems (Yackulic et al. 2014). Tributaries of the Colorado River, such as Shinumo Creek, may provide rearing opportunities similar to side-channel pools proposed by Minckley et al. (2003) for Humpback Chub and other threatened and endangered native fish. However, emigration from tributary systems (e.g., Shinumo Creek and Chute Falls within the Little Colorado) immediately following release is high. Alternative release techniques to control this initial dispersal may increase residence time and growth in the translocation stream, potentially increasing Humpback Chub survival in the mainstem Colorado River (Yackulic et al. 2014).

Despite high initial dispersal rates some Humpback Chub in Shinumo Creek are currently reaching sexual maturity (age 4, 200 mm TL; Keading and Zimmerman 1983; Valdez and Ryel 1995). Evidence of sexual maturation exists for Humpback Chub in Shinumo Creek. During the 2012 and 2013 monitoring events, 155 Humpback Chub displayed breeding coloration and 5 had frayed fin rays indicative of reproductive activity. Therefore, obtaining accurate estimates of reproduction and recruitment (i.e., larval abundance and survival) is needed to refine future conservation measures that could account for natural reproduction and recruitment. Additionally, relatively low abundances of translocated fishes may cause genetic concerns linked to lower levels of heterozygosity and allelic diversity, which was documented with translocated populations of Western Mosquitofish Gambusia affinis (Stockwell et al. 2002). Therefore, conservation actions may also need to consider that reintroductions may need to maintain gene flow and loss of genetic diversity of the translocated populations (USFWS 2010).

Alternative release strategies where individuals are held using block nets in the stream for a period of time (i.e., "soft releases" as compared to "hard releases" where individuals are immediately released without an acclimation period) may decrease high initial dispersal rates. However, few studies have evaluated soft releases of freshwater fishes, despite evidence that soft releases may improve retention rates (Brown and day 2002). Initial results of a soft release using block nets at Shinumo Creek in 2013 suggests that the method may be effective, because only 6 out of 200 fish released were detected at the antenna array during the $70 \mathrm{~d}$ after release (NPS, unpublished data). Experimentally releasing smaller size-classes of Humpback Chub may also highlight a strategy to reduce the initial dispersal from the system (Spurgeon 2012) but at the increased risk of predation from nonnatives and conspecifics (Paukert and Peterson 2007). Also, releasing larger numbers of individuals (i.e., increasing propagule pressure) may dampen the effects of high initial dispersal and increase the probability of establishment (Woodford et al. 2013).

Establishing an additional reproducing population of Humpback Chub and providing rearing opportunities for eventual augmentation of main-stem aggregations were defined as two potential major criteria of success (Trammell et al. 2012). Humpback Chub have grown at comparable rates to those remaining in the source population after translocation into Shinumo Creek, and recaptured individuals in the proximate main-stem aggregation after emigration suggests augmentation of the main-stem Colorado River populations may be occurring. Further research is needed to increase our understanding regarding alternative release strategies (e.g., soft releases and releasing different sizes), potential occurrence of reproduction and recruitment by Humpback Chub, and how outmigrants are contributing to the greater Humpback Chub population within Grand Canyon and the Colorado River. Additionally, translocation into other Colorado River tributaries may provide complementary outcomes. For instance, translocation efforts were expanded in 2011 to include Havasu Creek, where initial evidence suggests exceptionally high growth rates, lower dispersal, and evidence of reproduction, potentially leading to a redundant Humpback Chub population within Grand Canyon National Park. Our study suggests that efforts to conserve and manage endangered large-river fishes may be influenced by the often limited size of release groups and that additional management efforts to control for potentially high dispersal rates may be needed.

\section{ACKNOWLEDGMENTS}

Funding for this project was provided by the U.S. National Park Service through the Great Rivers Cooperative Ecosystems Study Unit (task agreement H6000080300), the U.S. Bureau of 
Reclamation, U.S. Geological Survey, and Natural Resources Preservation Program). We thank numerous biologists, technicians, volunteers, and others who helped with field collections, logistics, and all other aspects of the project. We particularly thank Larkin Powell, Joanna Whittier, and Daniel Whiting for help with analysis and discussions about the study. The Missouri Cooperative Fish and Wildlife Research Unit is jointly sponsored by the Missouri Department of Conservation, the University of Missouri, the U.S. Fish and Wildlife Service, the U.S. Geological Survey, and the Wildlife Management Institute. The use of trade names or products does not constitute an endorsement by the U.S. Government, the U.S. Geological Survey or other sponsoring or participating agencies. This research was permitted under NPS Scientific Research and Collecting Permit GRCA-2010-SCI-0010, study GRCA-00543.

\section{REFERENCES}

Allan, N. L. 1993. Distribution and abundance of fishes in Shinumo Creek in the Grand Canyon. Master's thesis. University of Arizona, Tuscon.

Brown, C., and R. L. Day. 2002. The future of stock enhancements: lessons learned for hatchery practice from conservation biology. Fish and Fisheries 3:79-94.

Brown, M. L., and B. R. Murphy. 1991. Relationship of relative weight $\left(W_{r}\right)$ to proximate composition of juvenile Striped Bass and hybrid Striped Bass. Transactions of the American Fisheries Society 120:509-518.

Coggins, L. G. Jr., and C. J. Walters. 2009. Abundance trends and status of the Little Colorado River population of Humpback Chub; an update considering data from 1989-2008. U.S. Geological Survey, Open-File Report 20091075, Reston, Virginia.

Cooch, E., and G. White. 2011. Program MARK: a gentle introduction. Colorado State University, Fort Collins.

Cucherousset, J., and J. D. Olden. 2011. Ecological impacts of nonnative freshwater fishes. Fisheries 36:215-230.

Deredec, A., and F. Courchamp. 2007. Importance of the Allee effect for reintroductions. Ecoscience 14:440-451.

Didenko, A. V., S. C. Bonar, and W. J. Matter. 2004. Standard weight $\left(W_{s}\right)$ equations for four rare desert fishes. North American Journal of Fisheries Management 24:697-703.

Finch, C. 2012. Manipulation of fish vital rates through ecosystem experimentation in a regulated river. Master's thesis. University of Florida, Gainsville.

Finch, C., W. E. Pine III, and K. E. Limburg. 2015. Do hydropeaking flows alter juvenile fish growth rates? A test with juvenile Humpback Chub in the Colorado River. River Research and Applications 31:156-164.

Freeman, M. C., Z. H. Bowen, K. D. Bovee, and E. R. Irwin. 2001. Flow and habitat effects on juvenile fish and abundance in natural and altered flow regimes. Ecological Applications 11:179-190.

Galat, D. L., L. H. Fredrickson, D. D. Humburg, K. J. Bataille, J. R. Bodie, J. Dohrenwend, G. T. Gelwicks, J. E. Havel, D. L. Helmers, J. B. Hooker, J. R. Jones, M. F. Knowlton, J. Kubisiak, J. Mazourek, A. C. McColpin, R. B. Renken, and R. D. Semlitsch. 1998. Flooding to restore connectivity of regulated, large-river wetlands. BioScience 48:721-733.

George, A. L., B. R. Kuhajda, J. D. Williams, M. A. Cantrell, P. L. Rakes, and J. R. Shute. 2009. Guidelines for propagation and translocation for freshwater fish conservation. Fisheries 34:529-545.

Gido, K. B., D. L. Propst, J. D. Olden, and K. R. Bestgen. 2013. Multi-decadal responses of native and introduced fishes to natural and altered flow regimes in the American Southwest. Canadian Journal of Fisheries and Aquatic Sciences 70:554-564.
Goodman, B. J., C. S. Guy, S. L. Camp, W. M. Gardner, K. M. Kappenman, and M. A. H. Webb. 2013. Shovelnose Sturgeon spawning in relation to varying discharge treatments in a Missouri River tributary. River Research and Applications 29:1004-1015.

Hubert, W. A., R. D. Gipson, and R. A. Whaley. 1994. Interpreting relative weights of Lake Trout stocks. North American Journal of Fisheries Management 14:212-215.

Humphries, P. C., L. G. Serafini, and A. J. King. 2002. River regulation and fish larvae: variation through space and time. Freshwater Biology 47:13071331.

Keading, L. R., and M. A. Zimmerman. 1983. Life history and ecology of the Humpback Chub in the Little Colorado and Colorado Rivers of the Grand Canyon. Transactions of the American Fisheries Society 112:577-594.

Lawler, J. J., and J. D. Olden. 2011. Reframing the debate over assisted colonization. Frontiers in Ecology and the Environment 9:569-574.

Lebreton, J., K. P. Burnham, J. Clobert, and D. R. Anderson. 1992. Modeling survival and testing biological hypotheses using marked animals: a unified approach with case studies. Ecological Monographs 62:67-118.

Marsh, P. C., and J. E. Brooks. 1989. Predation by Ictalurid catfish as a deterrent to re- establishment of hatchery-reared Razorback Sucker. Southwestern Naturalist 34:188-195.

Marsh, P. C., B. K. Kesner, and C. A. Pacey. 2005. Repatriation as a management strategy to conserve critically imperiled fish species. North American Journal of Fisheries Management 25:547-556.

Minckley, W. L. 1995. Translocation as a tool for conserving imperiled fishes: experiences in western United States. Biological Conservation 72:297-309.

Minckley, W. L., P. C. Marsh, J. E. Deacon, T. E. Dowling, P. W. Hedrick, W. J. Matthews, and G. Mueller. 2003. A conservation plan for native fishes of the lower Colorado River. BioScience 53:219-232.

Mueller, G. A., and R. Wydoski. 2004. Reintroduction of the Flannelmouth Sucker in the lower Colorado River. North American Journal of Fisheries Management 24:41-46.

Nesler, T. P., R. T. Muth, and A. F. Wasowicz. 1988. Evidence for baseline flow spikes as spawning cues for Colorado Squawfish in the Yampa River, Colorado. Pages 68-79 in R. D. Hoyt, editor. 11th Annual larval fish conference. American Fisheries Society, Symposium 5, Bethesda, Maryland.

Olden, J. D., M. J. Kennard, J. J. Lawler, and N. L. Poff. 2011. Challenges and opportunities in implementing managed relocation for conservation of freshwater species. Conservation Biology 25:40-47.

Paukert, C. P., L. G. Coggins Jr., and C. E. Flaccus. 2006. Distribution and movement of Humpback Chub in the Colorado River, Grand Canyon, based on recaptures. Transactions of the American Fisheries Society 135:539-544.

Paukert, C. P., and J. H. Peterson. 2007. Simulated effects of temperature warming on Rainbow Trout and Humpback Chub in the Colorado River, Grand Canyon. Southwestern Naturalist 52:234-242.

Pine, W. E. III, B. Healy, E. Omana Smith, M. Trammell, D. Speas, R. Valdez, M. Yard, C. Walters, R. Ahrens, R. Van Haverbeke, D. Stone, and W. Wilson. 2013. An individual based model for population viability analysis of Humpback Chub in Grand Canyon. North American Journal of Fisheries Management 33:626-641.

Poff, N. L. R., J. D. Allan, M. B. Bain, J. R. Karr, K. L. Prestegaard, B. D. Richter, R. E. Sparks, and J. C. Stromberg. 1997. The natural flow regime. BioScience 47:769-784.

Porath, M. T., and E. J. Peters. 1997. Use of relative weight $\left(W_{r}\right)$ to assess prey availability. North American Journal of Fisheries Management 17:628-637.

Powell, L. A. 2007. Approximating variance of demographic parameters using the Delta method: a reference for avian biologist. Condor 109:949-954.

Pracheil, B. M., P. B. McIntyre, and J. D. Lyons. 2013. Enhancing conservation of large-river biodiversity by accounting for tributaries. Frontiers in Ecology and the Environment 11:124-128.

R Development Core Team. 2014. R: a language and environment for statistical computing. R Foundation for Statistical Computing, Vienna. Available: http://www.R-project.org/. (March 2015). 
Robinson, A. T., R. W. Clarkson, and R. E. Forrest. 1998. Dispersal of larval fishes in a regulated river tributary. Transactions of the American Fisheries Society 127:772-786.

Schwartz, M. W., J. J. Hellmann, J. M. McLachlan, D. F. Sax, J. O. Borevitz, J. Brennan, A. E. Camacho, G. Ceballos, J. R. Clark, H. Doremus, R. Early, J. R. Etterson, D. Fielder, J. L. Gill, P. Gonzalez, N. Green, L. Hannah, D. W. Jamieson, D. Javeline, B. A. Minteer, J. Odenbaugh, S. Polasky, D. M. Richardson, T. L. Root, H. D. Safford, O. Sala, S. H. Schneider, A. R. Thompson, J. W. Williams, M. Vellend, P. Vitt, and S. Zellmer. 2012. Managed relocation: integrating the scientific, regulatory, and ethical challenges. BioScience 62:732-743.

Spurgeon, J. J. 2012. Translocation of Humpback Chub (Gila cypha) and foodweb dynamics in Grand Canyon National Park tributary streams. Master's thesis. University of Missouri, Columbia.

Spurgeon, J. J., C. P. Paukert, B. D. Healy, C. A. Kelley, and D. P. Whiting. In press. Can translocated native fishes retain trophic niche when confronted with a resident invasive? Ecology of Freshwater Fish. DOI: 10.1111/ eff.12160.

Stockwell, G. A., M. Mulvey, and G. L. Vinyard. 2002. Translocation and the preservation of allelic diversity. Conservation Biology 10:1133-1141.

Trammell, M., B. Healy, E. Omana Smith, and P. Sponholtz. 2012. Humpback Chub translocation to Havasu Creek, Grand Canyon National Park implementation and monitoring plan. U.S. National Park Service, Natural Resources Report NPS/GRCA/NRR-2012/686, Fort Collins, Colorado.

Trammell, M. A., R. A. Valdez, S. W. Carothers, and R. J. Ryel. 2002. Effects of a low steady summer flow experiment in the Grand Canyon, Arizona. Final Report prepared for the Grand Canyon Monitoring and Research Center, Flagstaff, Arizona.

Tweed, E. J., J. T. Foster, B. L. Woodworth, P. Oesterle, C. Kuehler, A. A. Lieberman, A. T. Powers, K. Whitaker, W. B. Monahan, J. Kellerman, and T. Telfer. 2003. Survival, dispersal, and home-range establishment of reintroduced captive-bred Puaiohi, Myadestes palmeri. Biological Conservation 111:1-9.

USFWS (U.S. Fish and Wildlife Service). 1995. Final biological opinion on the operation of Glen Canyon Dam. USFWS, Region 2, Phoenix, Arizona.

USFWS (U.S. Fish and Wildlife Service). 2008. Final biological opinion on the operation of Glen Canyon Dam. USFWS, Region 2, Phoenix, Arizona.

USFWS (U.S. Fish and Wildlife Service). 2010. A genetic management plan for captive and translocated endangered Humpback Chub in the lower
Colorado River basin. USFWS, Dexter National Fish Hatchery and Technology Center, Dexter, New Mexico.

USFWS (U.S. Fish and Wildlife Service). 2011. Final biological opinion on the operation of Glen Canyon Dam including high flow experiments and non-native fish control. U.S. Bureau of Reclamation, Upper Colorado Region, Salt Lake City, Utah.

Valdez, R. A., S. W. Carothers, M. E. Douglas, M. Douglas, R. J. Ryel, K. R. Bestgen, and D. L. Wegner. 2000. Research and implementation plan for establishing a second population of Humpback Chub in Grand Canyon. Final Report to the Grand Canyon Monitoring and Research Center, Flagstaff, Arizona.

Valdez, R. A., and R. J. Ryel. 1995. Life history and ecology of the Humpback Chub (Gila cypha) in the Colorado River, Grand Canyon, Arizona. Final Report to the U.S. Bureau of Reclamation, Salt Lake City, Utah.

Van Haverbeke, D. R., D. M. Stone, L. G. Coggins, and M. J. Pillow. 2013. Long-term monitoring of an endangered desert fish and factors influencing population dynamics. Journal of Fish and Wildlife Management 4:163-177.

Whiting, D. W., C. P. Paukert, B. D. Healy, and J. J. Spurgeon. 2014. Macroinvertebrate prey availability and food web dynamics of nonnative trout in a Colorado River tributary, Grand Canyon. Freshwater Science 33:872-884.

Williams, B. K., J. D. Nichols, and M. J. Conroy. 2002. Analysis and management of animal populations. Academic Press, San Diego.

Woodford, D. J., C. Hui, D. M., Richardson, and O. L. F. Weyl. 2013. Propagule pressure drives establishment of introduced freshwater fish: quantitative evidence from an irrigation network. Ecological Applications 23:19261937.

Yackulic, C. B., M. D. Yard, J. Korman, and D. R. Van Haverbeke. 2014. A quantitative life history of endangered Humpback Chub that spawn in the Little Colorado River: variation in movement, growth, and survival. Ecology and Evolution 4:1006-1018.

Yard, M. D., L. G. Coggins Jr., C. V. Baxter, G. E. Bennett, and J. Korman. 2011. Trout piscivory in the Colorado River, Grand Canyon: effects of turbidity, temperature, and fish prey availability. Transactions of the American Fisheries Society 140:471-486.

Zydlewski, G. B., G. Horton, T. Dubreuil, B. Letcher, S. Casey, and J. Zydlewski. 2006. Remote monitoring of fish in small streams: a unified approach using PIT tags. Fisheries 31:492-502. 